\title{
SALICYLIC ACID DEGRADATION FROM AQUEOUS SOLUTIONS USING PSEUDOMONAS FLUORESCENS HK44: PARAMETERS STUDIES AND APPLICATION TOOLS
}

\author{
Tatyane R. Silva' ${ }^{1}$ Erika Valdman²; Belkis Valdman; Selma G.F. Leite ${ }^{1 *}$ \\ ${ }^{1}$ Escola de Química, Universidade Federal do Rio de Janeiro, Centro de Tecnologia, Cidade Universitária, Rio de Janeiro, RJ, \\ Brasil; ${ }^{2}$ Centro de Tecnologia Mineral - CPMA/CETEM, Universidade Federal do Rio de Janeiro, Cidade Universitária, Rio de \\ Janeiro, RJ, Brasil
}

Submitted: December 20, 2005; Returned to authors for corrections: April 17, 2006; Approved: January 18, 2007

\begin{abstract}
The optimal conditions for salicylic acid biodegradation by Pseudomonas fluorescens HK44 were determined in this study with the intention to create a microbial sensor. Kinetic experiments permitted a definition of 60 and 30min the time needed to achieve the maximum degradation of salicylic acid presented in a medium with and without yeast extract, respectively. The degradation in medium without yeast extract and the quantification by spectrophotometry $230 \mathrm{~nm}$ were selected to be used in further tests. The use of preactivated cells or on the exponential growth phase showed better salicylic acid degradation percentages when compared to nonactivated cells or on the stationary growth state. Finally, the best cellular concentration used on the salicylic acid degradation was $0,1 \mathrm{~g} . \mathrm{L}^{-1}$. Strain HK44 shows to be capable of degrade salicylic acid presented in simple aqueous systems, making this strain a promising tool for the application on a luminescent microbial sensor.
\end{abstract}

Key words: salicylic acid, Pseudomonas fluorescens HK44, bioremediation

\section{INTRODUCTION}

Salicylic acid and its analogues are commonly used as effective analgesics and are available to the public in a wide variety of formulations. Despite their utility as pain relievers and antipyretics, salicylic acid can be quite toxic if taken in large doses (2). Recommended therapeutic levels in plasma range from 150 to $300 \mathrm{mg} \cdot \mathrm{L}^{-1}$. However, symptoms of intoxication may appear at $300 \mathrm{mg} \cdot \mathrm{L}^{-1}$ level, and severe sequelae of intoxication including tetany and acidosis may occur at levels more than $500 \mathrm{mg} . \mathrm{L}^{-1}$ (5).

The degradation of salicylic acid and the genetic basis of the metabolism have been investigated for decades with various bacteria. A majority of the bacteria able to utilize salicylic acid possess the enzyme required for the degradation of naphthalene or certain tricyclic aromatic hydrocarbons (6). All Pseudomonas strains tested capable of naphthalene degradation oxidize salicylic acid to cathecol and then cleaved via the meta-pathway (by cathecol-2,3-dioxygenase) or the orto-pathway (by cathecol-1,2,-dioxygenase). Salicylic acid can be also oxidized through gentisic acid (4).
Various methods for the determination of salicylic acid have been reported. These methods vary from colorimetry, fluorimetry and chromatography to ion selective electrodes and voltametric methods. The variety of published assay methods present problems of specificity, sensitivity and ease of operation required for the analysis of a large number of samples. Besides that, many of these techniques require time-consuming sample pretreatment steps (e.g., extraction, derivatization or preconcentration) that in some cases require special and expensive instrumentation (11). For this reason, spectrophotometric techniques were selected to evaluate the effectiveness of salicylic acid quantification. The simplest method for determining total salicylic acid is the Trinder reaction where the acid is quantified at the visible region (16). In this case, the salicylic acid reacts with ferric ions to form a purple complex in solution read on optical density of $530 \mathrm{~nm}\left(\mathrm{OD}_{530}\right)$. Although the Trinder test is rapid and inexpensive to perform, its selectivity is poor, since similar complexes can form with a variety of compounds, including phenolic compounds (e.g. tyrosine) and enolic metabolites (e.g. acetoacetate). The detection of salicylic acid in the ultraviolet region $\left(\mathrm{OD}_{230}\right)$ is an

*Corresponding Author. Mailing address: Escola de Química, Centro de Tecnologia, Universidade Federal do Rio de Janeiro, Bloco E, Lab. 103, Cidade Universidade - cep 21940-900 - Rio de Janeiro, RJ - Brasil. Tel.: (21) 2562-7613. E-mail: selma@eq.ufrj.br 
alternative to this technique as it is more specific for this compound (8).

Pseudomonas fluorescens HK44 is a bacteria that produces bioluminescent light in response to naphthalene $(14,18,19,20)$, salicylic acid or 4-methyl salicylate when physiological active during a bioremediation process (7). This strain is the first genetically modified organism allowed in the USA for bioremediation field application (12). It has been successfully used, free or immobilized, as a biosensor for determination of naphthalene (19) and salicylic acid bioavailability $(7,9,12,14,17)$.

Nevertheless, with the intention to create a microbial sensor as a new analytical tool for on line measurement of salicylic acid in aqueous systems, the optimal conditions for salicylic acid biodegradation by Pseudomonas fluorescens HK44 were determined in this study.

\section{MATERIALS AND METHODS}

\section{Bacterial growth and degradation media}

Selected bacteria Pseudomonas fluorescens HK44 was bought on the strain bank DMSZ, Germany, with the DMSZ 6700 register. This strain was incubated at $25^{\circ} \mathrm{C}$ for $24 \mathrm{~h}$ in YEPG (Yeast extract - Peptone - Glucose) medium with addition of tetracycline (15 mg. $\left.\mathrm{L}^{-1}\right)(18)$ for positive selection of this strain. After achieving stationary phase of growth, cells were centrifuged and resuspended in $10 \mathrm{~mL}$ of distilled water to obtain a concentrated cell suspension. To evaluate salicylic acid degradation, cell suspension was added to $0.1 \mathrm{M}$ potassium phosphate buffer ( $\mathrm{pH}$ 7.0) supplemented with salicylic acid (Merck LTDA) and/or yeast extract $(0.01 \%)$.

\section{Analytical methods}

To obtain the calibration curve for salicylic acid, two spectrophotometric methods were chosen, one in the ultraviolet region $\left(\mathrm{OD}_{230}\right)$ and the other in the visible region $\left(\mathrm{OD}_{530}\right.$ - Trinder test). A known salicylic acid mass was dissolved in distilled water containing or not yeast extract at $0.01 \%$ to evaluate the influence of this compound on biodegradation of this acid. From these concentrated solutions, different dilutions in distilled water were performed to obtain salicylic acid concentrations between 1 and $100 \mathrm{mg} . \mathrm{L}^{-1}$. For the $\mathrm{OD}_{230}$ method, the different dilutions of salicylic acid were analyzed directly on the spectrophotometer, without previous treatment. For the Trinder test, equal volumes of a $0.02 \mathrm{M} \mathrm{FeCl}_{3}$ solution and different salicylic acid dilutions were mixed and analyzed on the spectrophotometer at $530 \mathrm{~nm}$ after $5 \mathrm{~min}$ of reaction.

\section{Salicylic acid degradation}

Degradation experiments were carried out to assess optimal conditions for salicylic acid biodegradation by $P$. fluorescens HK44. All experiments were carried out on a shaker at $25^{\circ} \mathrm{C}, \mathrm{pH}$ 7.0 and $150 \mathrm{rpm}$ for $80 \mathrm{~min}$. Eight samples $(5 \mathrm{~mL})$ were taken from each erlenmeyer and filtered on acetate cellulose membranes $(0.45 \mu \mathrm{m}$ - Advanced MFS Inc.) every $10 \mathrm{~min}$. Filtered samples containing salicylic acid were quantified as described earlier.

Effect of yeast extract addition $(0.01 \%)$ to detection medium. This parameter was assessed using cells at stationary phase of growth $\left(0.4 \mathrm{~g} . \mathrm{L}^{-1}\right)$ and salicylic acid solution $\left(100 \mathrm{mg} . \mathrm{L}^{-1}\right)$ in 0.1 $\mathrm{M}$ phosphate buffer ( $\mathrm{pH}$ 7.0). Solutions containing concentrated cells were obtained by dry weight method.

Response to different salicylic acid concentrations, different physiological state of cells and cellular preactivation. The response to different salicylic acid concentrations $(25,50,100$ and $200 \mathrm{mg} \cdot \mathrm{L}^{-1}$ ), physiological state of cells (exponential and stationary phase of growth) and cellular pre-activation was also verified maintaining $0.4 \mathrm{~g} . \mathrm{L}^{-1}$ cellular concentration. The choice of these four different salicylic acid concentrations was guided by the maximum concentration of this acid permitted for environmental effluents, which is $100 \mathrm{mg} \cdot \mathrm{L}^{-1}$. Then, we wanted to evaluate if Pseudomonas fluorescens HK44 would degrade amounts of salicylic acid ranging between this value. The last two parameters were tested using $100 \mathrm{mg} . \mathrm{L}^{-1}$ salicylic acid solution in phosphate buffer. The pre-activation of the enzymes involved on the biodegradation of this acid were carried out after cellular growth by adding salicylic acid to a final concentration of $25 \mathrm{mg} . \mathrm{L}^{-1}$. Pre-grown cells were then incubated overnight, centrifuged and resuspended in $10 \mathrm{~mL}$ of distilled water to obtain the cellular suspension.

Effect of cellular concentration $\left(0.1,0.2,0.4,0.6,0.8\right.$ and 1.0 g.L $\left.\mathrm{L}^{-1}\right)$. Each concentration was tested for salicylic acid solutions of 25, 100 and $200 \mathrm{mg} . \mathrm{L}^{-1}$. Specific removal of salicylic acid (quantity of salicylic acid removed per quantity of cells) and removal rate (quantity of salicylic acid removed per quantity of cell per minute) were also calculated for each salicylic acid and cell concentration used.

\section{RESULTS AND DISCUSSION}

\section{Salicylic acid quantification}

Calibration curves for salicylic acid were shown to be linear from 1 to $100 \mathrm{mg} . \mathrm{L}^{-1}$. Equations obtained from these curves were used in all experiments to determine the salicylic acid degradation.

It can be seen that there is no a significant difference between salicylic acid solutions with or without the addition of $0.01 \%$ yeast extract comparing both methods used as calibration curves showed to be very similar.

\section{Salicylic acid degradation}

Effect of yeast extract addition to detection medium. It can be noted, by ultraviolet spectrophotometry, that salicylic acid 
degradation was higher in the presence of yeast extract, achieving $95 \%$ of degradation, when compared to degradation without this compound, that was $69 \%$ (Fig. 1).

The maximum degradation time tested (80min) was sufficient to complete salicylic acid degradation as no significant degradation percentage was verified after that period (data not shown). However, after $60 \mathrm{~min}$, the increase on degradation percentage, using ultraviolet spectrophotometry, to the medium added of yeast extract was very low. To the medium to which yeast extract was not added, degradation occurred after $30 \mathrm{~min}$. Hence, good salicylic acid degradation percentages can be obtained at times less than $80 \mathrm{~min}$. This profile shows that the total time of experiments could be decreased, which would optimize the process.

Valdman (18) also studied the addition of yeast extract to the detection medium in the presence of naphthalene and P. fluorescens HK44. It was observed (14) that continuous bioluminescence decreased almost two-fold the initial time response when compared to the time obtained with the detection medium with sodium salicylate or water. In this work, we observed that the addition of yeast extract decreased the time of salicylic acid degradation and increased the degradation percentage of this acid.

According to Filonov et al. (4), addition of a carbon source as nutrient increases cellular activity, stimulating the growth of microorganisms capable of degrading the interest compound. However, this same carbon source can inhibit degradation of some compounds, resulting in diauxic growth. Hence, it is important to add the optimal quantity of nutrients to degradation estimated from kinetic growth and yield coefficients. It is a well known fact that the addition of nutrients below or above the optimal quantity would result in a slow or stop the degradation, respectively. In this work, authors studied the effect of an additional carbon source on naphthalene degradation by Pseudomonas putida G7.

Response to different salicylic acid concentrations. It can be observed that 25 and $50 \mathrm{mg} . \mathrm{L}^{-1}$ salicylic acid concentrations were degraded more efficiently, achieving 92 and $94 \%$ degradation, respectively, when compared to 100 and $200 \mathrm{mg} . \mathrm{L}^{-1}$ concentrations (69 and 58\%, respectively - Fig. 2). This can be possibly explained by the fact that the salicylic acid degradation by P. fluorescens HK44 was inhibited at high concentrations of this substrate.

A similar degradation profile was already observed for the bacterium Ralstonia taiwanensis that presented inhibition by phenol at concentrations higher than $853 \mathrm{mg} . \mathrm{L}^{-1}$ after $36 \mathrm{~h}$ of experiment (3). The degradation percentage obtained with 100 mg. $\mathrm{L}^{-1}$ of salicylic acid concentration $(69 \%)$ was higher than verified by Matrubutham et al. (9) using the same strain. At the same concentration, only 50 to $60 \%$ salicylic acid was degraded after 35 days of experiment.
Effect of different physiological state of cells. The effect of different physiological state of cells can be seen on Fig. 3.

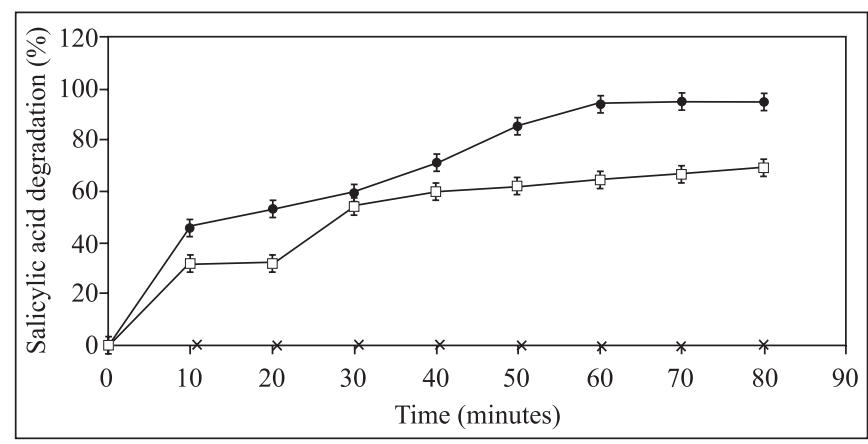

Figure 1. Kinetics of salicylic acid degradation, with $(\bullet)$ and without yeast extract at $0.01 \%(\square)$ by ultraviolet spectrophotometry, using $230 \mathrm{~nm}$ (cellular concentration $=$ $0.4 \mathrm{~g} . \mathrm{L}^{-1} ;$ initial salicylic acid concentration $=100 \mathrm{mg} \cdot \mathrm{L}^{-1} ; \mathrm{pH}=$ 7.0; control $=$ distilled water $(\mathrm{x})) \cdot \mathrm{n}=3$

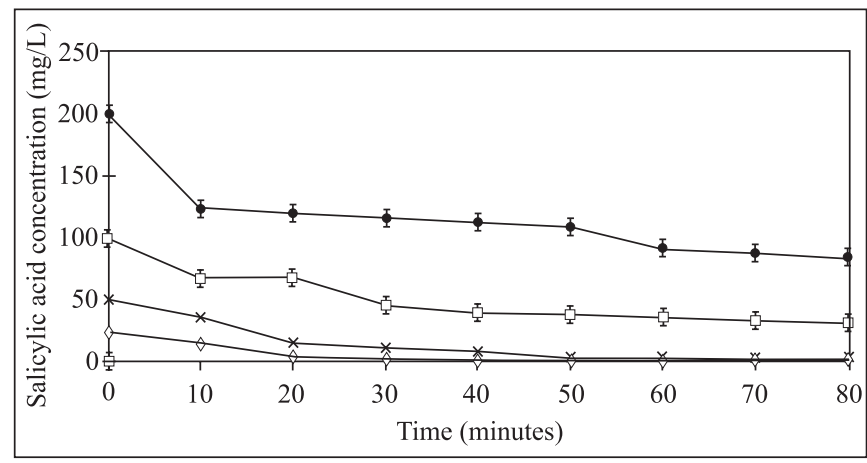

Figure 2. Response to different initial salicylic acid concentrations $(\diamond) 25 \mathrm{mg} \cdot \mathrm{L}^{-1} ;(\mathrm{x}) 50 \mathrm{mg} \cdot \mathrm{L}^{-1} ;(\square) 100 \mathrm{mg} \cdot \mathrm{L}^{-1} ;(\bullet)$ $200 \mathrm{mg} \cdot \mathrm{L}^{-1}$ (cellular concentration $=0.4 \mathrm{~g} \cdot \mathrm{L}^{-1} ; \mathrm{pH}=7.0$ ). $\mathrm{n}=3$.

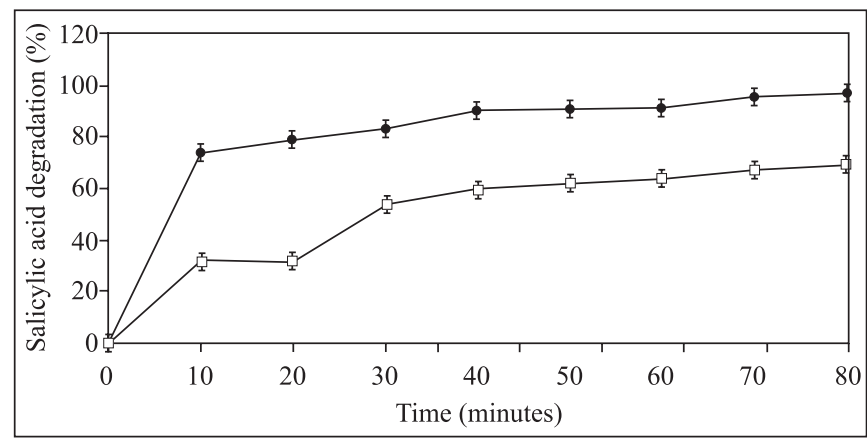

Figure 3. Effect of stationary $(\square)$ and exponential $(\bullet)$ growth phase of Pseudomonas fluorescens HK44 (cellular concentration $=0.4 \mathrm{~g} \cdot \mathrm{L}^{-1} ;$ salicylic acid initial concentration $=100 \mathrm{mg} \cdot \mathrm{L}^{-1} ; \mathrm{pH}=$ 7.0). $\mathrm{n}=3$. 
It can be noted that salicylic acid degradation percentage was higher $(97 \%)$ when cells on exponential phase were used, when compared to cells on the stationary state (69\%). This can be explained by the fact that cells on exponential phase are already preactivated and are capable of degrade their substrates faster than cells on stationary state.

Effect of cellular preactivation. Preactivation, which is the enzymatic induction of biological activities of the cell, affected salicylic acid degradation by strain HK44. Preactivated cells showed evidence of increased salicylic acid degradation during the period of exposure to $100 \mathrm{mg} . \mathrm{L}^{-1}$ (Fig. 4). We can observe that the maximum salicylic acid degradation percentage increased from 69 to $89 \%$ when preactivated cells were used. Other interesting fact is that preactivated cells presented a salicylic acid degradation percentage almost $50 \%$ higher than that presented by non activated cells in the first $10 \mathrm{~min}$. This can be explained by the fact that the biological activities of the cell were previously induced by the preactivation process. Besides that, salicylic acid degradation by $P$. fluorescens HK44 showed no lag phase both when using preactivated and non activated cells.

The results obtained by these experiments showed to be in agreement with the literature. Sodium salicylate solutions on distilled water or YEP medium were used as inductors to Pseudomonas fluorescens HK44 (14). In this study, preactivated cells showed an activity higher than non activated cells. Valdman (18) also observed an increase of maximum bioluminescence value when preactivated cells of strain HK44 were used to degrade naphthalene.

Effect of cellular concentration. The kinetic of salicylic acid degradation at different concentrations and the specific hydrocarbon degradation can be seen on Fig. 5 .

It can be noted that the specific salicylic acid degradation was higher when decreasing cellular concentration. This profile was not observed only at the lowest salicylic acid concentration

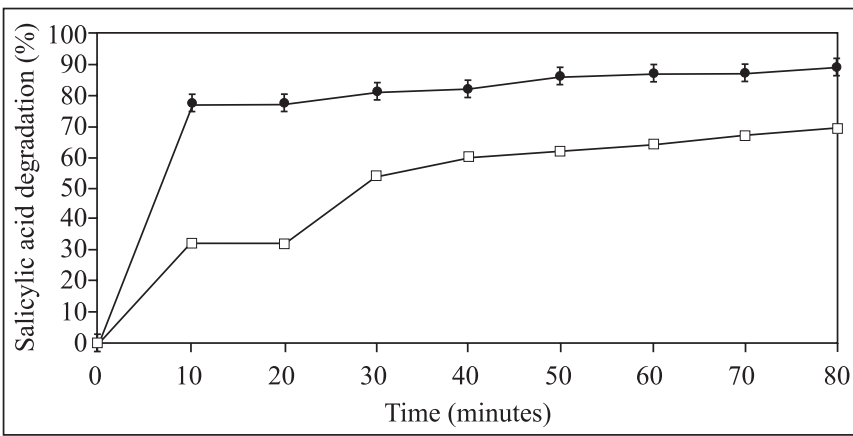

Figure 4. Salicylic acid degradation by pre-activated $(\bullet)$ and non activated ( $\square$ ) cells of Pseudomonas fluorescens HK44 (cellular concentration $=0.4 \mathrm{~g} \cdot \mathrm{L}^{-1}$; initial salicylic acid $) . \mathrm{n}=3$. studied, that was $25 \mathrm{mg} . \mathrm{L}^{-1}$ (Fig. 5c), where $0.2 \mathrm{~g} . \mathrm{L}^{-1}$ was the cellular concentration that obtained the best specific degradation. This fact can be explained by three ways:

On higher cellular densities, cells can be limited by oxygen, resulting on a lower salicylic acid degradation. Applegate et al. (1) verified this behavior on experiments with toluene and Escherichia coli bearing fabA':lux fusions. More recently, Valdman (18) observed that a lower signal of bioluminescence produced by strain HK44 was achieved with increasing cell density and that dissolved oxygen also affected the response.

Another possibility is the production of toxic intermediates from the salicylic acid biodegradation. Higher cell concentrations of Pseudomonas fluorescens HK44 could degrade more salicylic acid, producing higher quantities of the possible toxic

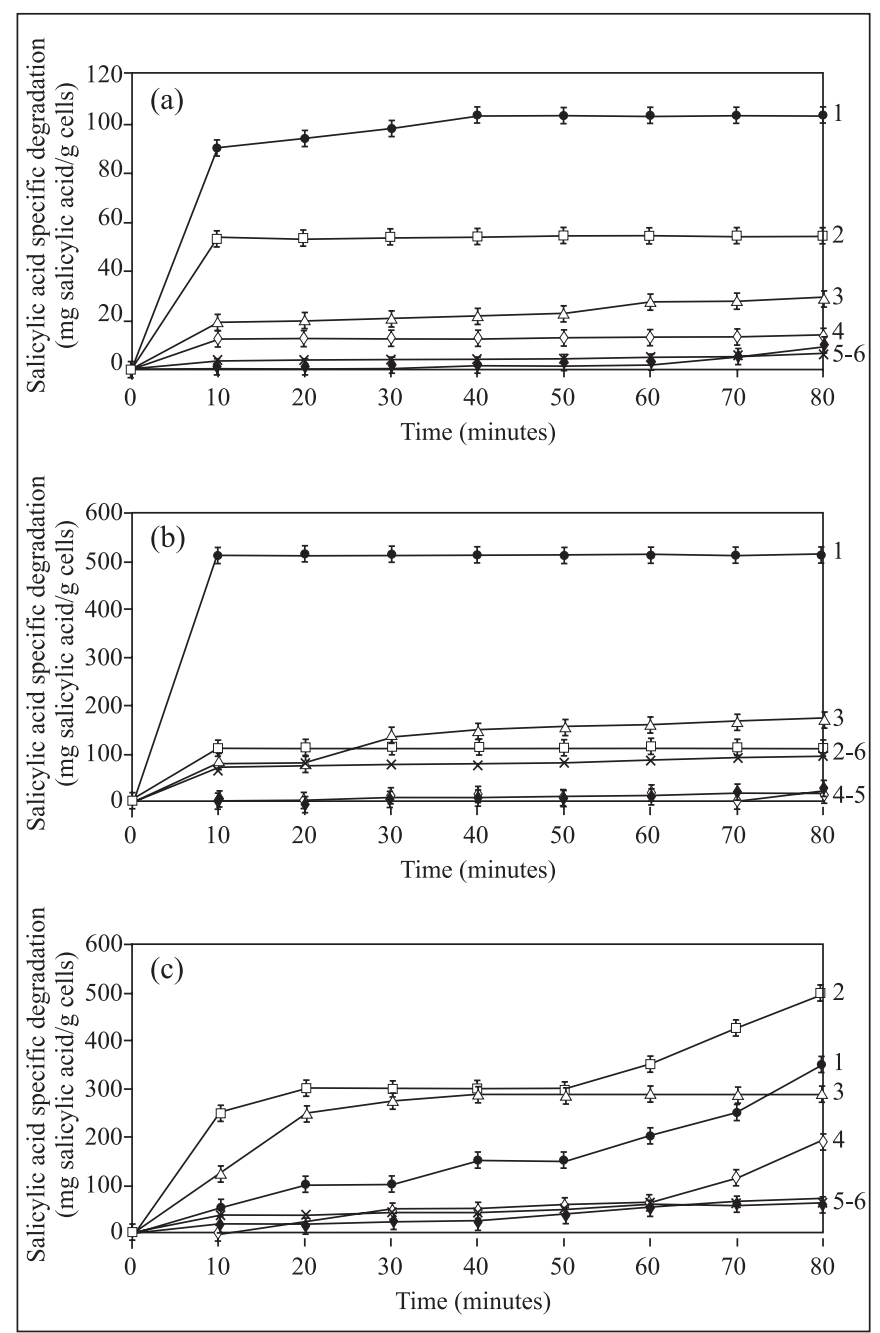

Figure 5. Specific degradation of salicylic acid (a) $200 \mathrm{mg} . \mathrm{L}^{-1}$; (b) $100 \mathrm{mg} . \mathrm{L}^{-1}$ and (c) $25 \mathrm{mg} \cdot \mathrm{L}^{-1}$ using different cell concentrations

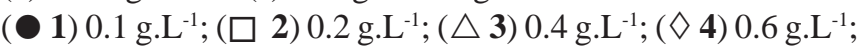
( 5) 0.8 g.L. $\mathrm{L}^{-1} ;(\mathbf{x} 6) 1.0$ g.L. $\mathrm{L}^{-1}(\mathrm{pH}=7.0) . \mathrm{n}=3$. 
intermediate that could inhibit cells to degrade the rest of the acid. This profile was already observed in some experiments with other microorganisms. An example of this is the fluoranthene biodegradation inhibition by Pseudomonas putida due to low molecular weight intermediates, mostly benzoic acid (15). Besides this work, Rover Jr. (13) also verified an interference of gentisic 3-hydroxy-benzoic, 4-hidroxybenzoic and o-aminobenzoic acid on the response of an amperometric biosensor for salicylic acid, due to structural similarities between these compounds and salicylic acid.

Another explanation could be that Pseudomonas fluorescens HK44 present a quorum sensing behavior. Quorum sensing is defined as a form of cell-to-cell communication by use of little signalizing molecules. Once thought as a rare phenomena, now is very apparent that an extensive variety of microorganisms have the ability to perceive and response to the presence of neighbor microbial populations. Numerous signalizations mediated by signaling molecules and response pathways have been defined and many of them are considered as a regulation form (21). This behavior is very common on Gram-negative bacteria and has already been related to Pseudomonas fluorescens, mediated by the molecule carboxylic-1-fenanzine acid (10). This could justify the state of low metabolism of Pseudomonas fluorescens HK44 cells, decreasing the salicylic acid removal with increasing cell concentration.

To better compare salicylic acid degradation by different cell concentrations, the specific degradation rate of salicylic acid (quantity of salicylic acid removed per quantity per cells by minute) was calculated for each salicylic acid and cell concentrations used from the values obtained for each one of these points after 10min of experiment (see Fig. 6). This period was chosen as a small increase on percentage removal was observed after on (Fig. 5).

It can be noticed that the specific degradation rate of salicylic acid was higher when lower was the cell concentration used,

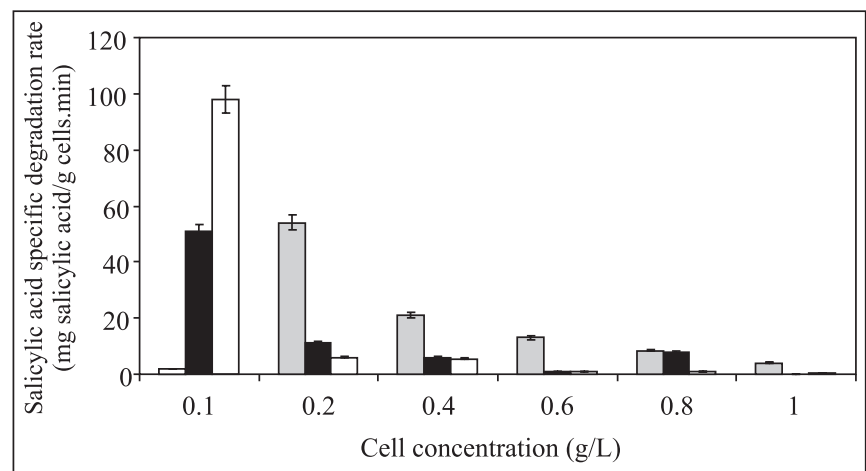

Figure 6. Specific degradation rate of salicylic acid ( $\square$ ) 25

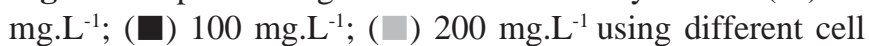
concentrations in $10 \mathrm{~min}$ of experiment $(\mathrm{pH}=7.0) . \mathrm{n}=3$. independently of acid concentration, indicating better removal rates with $0.1 \mathrm{~g}_{\text {cell }} \cdot \mathrm{L}^{-1}$. This profile was not observed at salicylic acid concentration of $25 \mathrm{mg} . \mathrm{L}^{-1}$, where the best specific degradation rate was obtained with cell concentration of 0.2 g. $\mathrm{L}^{-1}$. Lower cell concentrations probably produce less toxic intermediates, not sufficient to cause toxicity to cells.

\section{CONCLUSIONS}

Pseudomonas fluorescens HK44 strain showed to be capable of degrade salicylic acid present in simple aqueous systems. This makes this strain a promising tool for the application on a luminescent microbial sensor to detect and quantify salicylic acid. Tests with strain HK44 were carried out to degrade salicylic acid at different concentrations. Kinetic experiments permitted a definition of 60 and $30 \mathrm{~min}$ the time needed to achieve the maximum degradation of salicylic acid presented in a medium with and without yeast extract, respectively. From the preliminary experiments, the degradation in medium without yeast extract and the quantification by spectrophotometry $230 \mathrm{~nm}$ seem to be more adequate to further tests. The use of preactivated cells or on the exponential growth phase showed better salicylic acid degradation percentages when compared to nonactivated cells or on the stationary growth state. The best cellular concentration used on the salicylic acid degradation was 0.1 g. $\mathrm{L}^{-1}$, obtaining $61 \%$ degradation for both 200 and $100 \mathrm{mg} \cdot \mathrm{L}^{-1}$ acid concentrations. So, Pseudomonas fluorescens HK44 shows to be capable of degrade salicylic acid presented in simple aqueous systems and further tests are needed to show if this strain behaves the same way when in the presence of complex matrices.

\section{ACKNOWLEDGEMENTS}

The authors are grateful to Conselho Nacional de Desenvolvimento Científico e Tecnológico, Fundação Carlos Chagas Filho de Amparo à Pesquisa do Estado do Rio de Janeiro, Fundação Universitária José Bonifácio and Coordenação de Aperfeiçoamento de Pessoal de Nível Superior for financial support.

\section{RESUMO}

\section{Degradação de ácido salicílico presente em soluções sintéticas utilizando Pseudomonas fluorescens HK44}

Com a intenção de criar um sensor microbiano, as condições ótimas para a biodegradação de ácido salicílico por Pseudomonas fluorescens HK44 foram determinadas neste estudo. Os experimentos cinéticos permitiram a definição dos tempos de $60 \mathrm{e}$ 30 minutos como necessários para atingir a máxima degradação de ácido salicílico presente em meio com ou sem extrato de lêvedo, respectivamente. A degradação no meio sem extrato de lêvedo e 
a quantificação através de espectrofotometria $230 \mathrm{~nm}$ foram selecionadas para serem utilizadas em testes posteriores. $\mathrm{O}$ uso de células pré-ativadas ou na fase exponencial de crescimento apresentou melhores porcentagens de degradação de ácido salicílico quando comparadas a células não-ativadas ou no estado estacionário de crescimento. Além disso, a melhor concentração celular utilizada nessa degradação foi 0,1 g.L. ${ }^{1}$. A cepa HK44 parece ser capaz de degradar o ácido salicílico presente em sistemas aquosos simples, tornando este microrganismo uma ferramenta promissora para aplicação em um sensor microbiano luminescente.

Palavras-chave: ácido salicílico, Pseudomonas fluorescens HK44, biorremediação

\section{REFERENCES}

1. Applegate, B.M.; Smulski, D.R.; Van Dyk, T.K.; Larossa, R.A.; Belkin, S. (2002). Recombinant microorganisms as environmental biosensors: pollutants detection by Escherichia coli bearing fabA' $\because$ lux fusions. J. Biotech., 94, 125-132.

2. Chaniotakis, N.A.; Park, S.B.; Meyerhoff, M.E. (1989). Salicylateselective membrane electrode based o tin (IV) tetraphenylporphyrin. Anal. Chem., 61, 566-570.

3. Chen, W.M.; Chang, J.S.; Wu, C.H.; Chang, S.C. (2004). Characterization of phenol and trichloroethene degradation by the rhizobium Ralstonia taiwanensis. Res. Microbiol., 155, 672680 .

4. Filonov, A.E.; Karpov, A.V.; Kosheleva, I.A.; Puntus, I.F.; Balashova, N.V.; Boronin, A.M. (2000). The efficiency of salicylate utilization by Pseudomonas putida strains catabolizing naphthalene via different biochemical pathways. Proc. Biochem., 35, 983-987.

5. Goto, Y.; Makino, K.; Kataoka, Y.; Shuto, H. (1998). Determination of salicylic acid in human serum with capillary zone electrophoresis. J. Chromatogr. B., 706, 329-335.

6. Kesserü, P.; Kiss, I.; Bihari, Z.; Pál, K.; Portörö, P.; Polyák, B. (2005). Nitrate-dependent salicylate degradation by Pseudomonas butanovora under anaerobic conditions. Bioresour. Technol., 96, 779-784.

7. King, J.M.H.; Digrazia, P.M.; Applegate, B.; Burlage, R.; Sanseverino, J.; Dunbar, P.; Larimer, F.; Sayler, G.S. (1990). Rapid, sensitive bioluminescente reporter technology for naphthalene exposure and biodegradation. Science, 249, 778-781.
8. Kokot, Z.; Burda, K. (1998). Simultaneous determination of salicylic acid and acetylsalicylic acid in aspirin delayed-release tablet formulations by second-derivative UV spectrophotometry. J. Pharm. Biomed. Anal., 18, 871-875.

9. Matrubutham, U.; Thonnard, J.E.; Sayler, G.S. (1997). Bioluminescence induction response and survival of the bioreporter bacterium Pseudomonas fluorescens HK44 in nutrient-deprived conditions. Appl. Microbiol. Biotechn., 47, 604-609.

10. Mavrodi, D.V.; Ksenzenko, V.N.; Chatuev, B.M.; Thomashow, L.S.; Boronin, A.M. (1997). Structural and functional organization of Pseudomonas fluorescens genes encoding enzymes of phenazine-1carboxylic acid biosynthesis. Mol. Biol., 31, 74-80.

11. Moore, T.J.; Joseph, M.J.; Allen, B.W.; Coury, L.A. (1995). Enzymatically amplified voltametric sensor for microliter sample volumes of salicylate. Anal. Chem., 67, 1896-1902.

12. Ripp, S.; Nivens, D.E.; Werner, C.; Sayler, G.S. (2000). Bioluminescent most-probable-number monitoring of a genetically engineered bacterium during a long-term contained field release. Appl. Microbiol. Biotechn., 53, 736-741.

13. Rover Jr., L. (1999). Construção e avaliação de biossensor amperométrico para salicilato usando salicilato hidroxilase imobilizada em matriz de polipirrol com glutaraldeído. São Paulo, 120p. (DSc. Thesis. Instituto de Química. Unicamp).

14. Sayler, G.S.; Ripp, S. (2000). Field applications of genetically engineered microorganisms for bioremediation processes. Curr. Op. Biotech., 11, 286-289.

15. Sepic, E.; Bricelj, M.; Leskovsek, H. (2003). Toxicity of fluoranthene and its biodegradation metabolites to aquatic organisms. Chemosphere, 52, 1125-1133.

16. Trinder, P. (1954). Rapid determination of salicylate in biological fluids. Biochem. J., 57, 301-303.

17. Trögl, J.; Ripp, S.; Kuncová, G.; Sayler, G.S.; Churavá, A.; Parík, P.; Demnerová, K.; Hálová, J.; Kubicová, L. (2004). Selectivity of whole cell optical biosensor with immobilized bioreporter Pseudomonas fluorescens HK44. Sens. Act. B.

18. Valdman, E. (2004). Desenvolvimento e aplicação de um biossensor luminescente para detecção de naftaleno. Rio de Janeiro, 124p. (DSc. Thesis. Escola de Química. UFRJ).

19. Valdman, E.; Battaglini, F.; Leite, S.G.F.; Valdman, B. (2004). Naphthalene detection by a luminescence sensor applied to wastewater samples. Sens. Act. B., 103, 7-12.

20. Valdman, E.; Valdman, B.; Leite, S.G.F.; Battaglini, F. (2004). On line detection of low naphthalene concentrations by a bioluminescent sensor. Proc. Biochem., 39, 1217-1222.

21. Whitehead, N.A.; Barnard, A.M.L.; Slater, H.; Simpson, N.J.L.; Salmond, G.P.C. (2001). Quorum-sensing in Gram-negative bacteria. FEMS Microbiol. Rev., 25, 365-404. 